\title{
Certainties and uncertainties about the life cycle of the Périgord black truffle (Tuber melanosporum Vittad.)
}

\author{
François Le Tacon • Andrea Rubini - Claude Murat - Claudia Riccioni • \\ Christophe Robin • Beatrice Belfiori • Bernd Zeller • Herminia De la Varga • \\ Emila Akroume • Aurélie Deveau • Francis Martin • Francesco Paolocci
}

Received: 7 November 2014 / Accepted: 13 January 2015 /Published online: 19 February 2015

(C) INRA and Springer-Verlag France 2015

\begin{abstract}
- Key message Several aspects of the life cycle of the Périgord black truffle have been elucidated only recently, while others remain either controversial or unstudied. In this paper, we present a revised life cycle of this fungus and highlight key aspects that have yet to be addressed or require further understanding.
\end{abstract}

\footnotetext{
Handling Editor: Anna Rincon

Contribution of the co-authors François Le Tacon: conceived the paper, wrote the first draft and edited the manuscript. Francesco Paolocci: supervised, coordinated the review and edited the manuscript. Andrea Rubini, Claude Murat, Claudia Riccioni, Christophe Robin, Beatrice Belfiori, Bernd Zeller, Herminia De la Varga, Emila Akroume, Aurélie Deveau and Francis Martin: previously obtained important findings reported in this review and contributed to correct or to rewrite the different sections.
}

F. Le Tacon $(\bowtie) \cdot$ C. Murat $\cdot$ H. De la Varga $\cdot$ E. Akroume $\cdot$

A. Deveau $\cdot$ F. Martin

INRA, Centre de Nancy Lorraine, UMR 1136, Interactions Arbres/

Microrganismes (IAM), Labex ARBRE,

54280 Champenoux, France

e-mail: le_tacon@nancy.inra.fr

C. Murat

e-mail: claude.murat@nancy.inra.fr

H. De la Varga

e-mail: Herminia.Delavargapastor@nancy.inra.fr

E. Akroume

e-mail: emila.akroume@nancy.inra.fr

A. Deveau

e-mail: Aurelie.Deveau@nancy.inra.fr

F. Martin

e-mail: fmartin@nancy.inra.fr

F. Le Tacon $\cdot$ C. Murat $\cdot$ A. Deveau $\cdot$ F. Martin

Université de Lorraine, UMR 1136, Interactions Arbres/

Microrganismes (IAM), Faculté des Sciences, Labex ARBRE,

54500 Vandoeuvre-les-Nancy, France
- Context The hypogeous sporophores of several Tuber species, renowned for their aromatic and gustatory qualities, are widely commercialized. One of the most valuable species is Tuber melanosporum Vittad., the Périgord black truffle also known as "the black diamond". However, many aspects of T. melanosporum life cycle remain unsolved.

- Aims In this work, we examine past and recent findings on the life cycle of $T$. melanosporum, currently regarded as a model system for Tuber species, with the view of highlighting aspects of its life cycle which remain unsolved.

- Results Several aspects of its life cycle have recently been elucidated (i.e. characterization of two mating type genes, heterothallism, prevalence of sexual reproduction on vegetative propagation, exclusion of one mating type by its opposite on ectomycorrhizas, dependency of ascocarps on their host for carbon allocation), while others remain unaddressed.

A. Rubini $\cdot$ C. Riccioni - B. Belfiori - F. Paolocci

National Research Council, Institute of Biosciences and

Bioresources, Perugia Division, Via della Madonna Alta 130, 06128 Perugia, Italy

A. Rubini

e-mail: andrea.rubini@igv.cnr.it

C. Riccioni

e-mail: claudia.riccioni@igv.cnr.it

B. Belfiori

e-mail: beatrice.belfiori@igv.cnr.it

F. Paolocci

e-mail: francesco.paolocci@ibbr.cnr.it

C. Robin

Université de Lorraine, UMR 1121 « Agronomie \& Environnement »

Nancy-Colmar, 54518 Vandœuvre-les-Nancy, France

e-mail: Christophe.robin@univ-lorraine.fr

B. Zeller

INRA, Centre de Nancy Lorraine, UR 1138, Biogéochimie des

Ecosystèmes Forestiers (BEF), Labex ARBRE,

54280 Champenoux, France

e-mail: zeller@nancy.inra.fr 
- Conclusion Numerous additional aspects of the T. melanosporum life cycle remain unsolved, such as exclusion or competition mechanisms between ectomycorrhizal mating types, factors involved in ascocarp initiation, the nature of the connection linking ascocarps and mycorrhizas and atmospheric nitrogen fixation.

Keywords Mating type $\cdot$ Competition $\cdot$ Male and female gametes $\cdot$ Black truffle

\section{Introduction}

The genus Tuber belongs to the Ascomycota, Discomycetes, Pezizomycota, Pezizomycetes, Pezizales and Tuberaceae. It comprises at least 180 species (Bonito et al. 2013). Index Fungorum recognizes 290 species, subspecies and varieties. The genus Tuber displays a large geographic distribution, but only in the Northern hemisphere (Jeandroz et al. 2008). It is found throughout all of Europe including Scandinavia (Gotland Island in Sweden) (Weden et al. 2004). Some species are found in North Africa (Ceruti et al. 2003). The genus Tuber is widespread in Asia (India, China, Mongolia) and present in North America (Bonito et al. 2013).

The hypogeous sporophores of several Tuber species, renowned for their flavour, are widely commercialized. The most valuable species, by virtue of their aromatic and gustatory qualities, are the three European species, Tuber magnatum Pico (Piedmont white truffle), Tuber melanosporum Vittad. (Périgord black truffle, also known as "the black diamond") and Tuber aestivum Vittad. (Burgundy truffle).

In this work, we examine past and recent findings on the life cycle of T. melanosporum, currently regarded as a model system for Tuber species, with the view of highlighting aspects of its life cycle which remain unsolved.

\section{Lessons from the past}

It has long been observed that Périgord black truffles grow near tree roots, mainly those of oaks. In 1808, in the Vaucluse department at Saint-Saturnin-les-Apt, a Frenchman, Joseph Talon, sowed acorns at the foot of trees which had produced Périgord black truffles and then transplanted the infected seedlings to new locations (Olivier et al. 2012). Several years later, he observed Périgord black truffle ascocarps growing on his plantations. At the end of the nineteenth century, the Minister of Agriculture of Prussia directed a German forester, Albert Bernhard Frank, to explore possibilities for truffle cultivation. In 1885, Frank discovered the symbiotic relationship that exists between fungi and tree roots and called this fungus-root association "mykorhiza"(Frank 1885). He also drew an illustration representing a beech ectomycorrhiza found in the vicinity of a truffle. Indeed, the drawn ectomycorrhiza does not look like a true Tuber ectomycorrhiza. Frank was not the first to describe ectomycorrhizas; however, he was the first to understand their function. Dangeard (1894) described T. melanosporum ectomycorrhizas on Quercus pubescens L. From 1890 to 1932, Mattirolo in Torino made numerous observations on truffle mycorrhizas (Mattirolo 1914). The first experimental proof that Tuber spp. have the capacity to establish a symbiotic association with roots of their hosts was obtained only in the late 1960s when Fassi and Fontana (1967) succeeded in inducing the synthesis of ectomycorrhizas through the inoculation of Pinus strobus L. with Tuber maculatum Vittad. Likewise, Palenzona (1969) succeeded in establishing mycorrhizal synthesis of T. melanosporum, T. aestivum and Tuber brumale Vittad. on Corylus avellana L. In the 1970s, then Chevalier and colleagues produced T. melanosporum and T. brumale mycorrhizas under axenic conditions (Grente et al. 1972; Chevalier 1973; Chevalier et al. 1973; Chevalier and Desmas 1977).

More recently, studies based on genetic and genomic approaches (i.e. release of the genome sequence) have helped mycologists to take a leap toward understanding the life cycle and reproductive modes of these fungi (Lanfranco et al. 1995; Rubini et al. 2007; Kües and Martin 2011; Rubini et al. 2014). While these studies succeeded in solving some important questions, they also brought to light unexpected features of the life cycle of these fungi.

\section{Questions recently answered}

\subsection{T. melanosporum is a heterothallic fungus}

Within the Ascomycetes, sexually reproducing species usually follow one of the three basic sexual productive strategies: homothallic, pseudohomothallic (or secondary homothallic) and haploid heterothallic (Leisle and Klein 1996). Differing to that for homothallic and pseudohomothallic species, in heterothallic fungi, same clone mating is prevented. The impossibility of mating truffle mycelia under controlled conditions has precluded the investigation of their mating strategies by direct approaches. Nevertheless, population genetics studies have been used to address this key biological aspect. Bertault et al. $(1998,2001)$ were the first to use co-dominant molecular markers for a large-scale screening of T. melanosporum populations and found an extremely low level of polymorphism over the whole study area as well as the absence of any heterozygote ascocarp. These authors then concluded that the narrow genetic variability among populations resulted from a population bottleneck experienced by this species during the last glacial period, while 
the absence of heterozygotes was due to homothallism or even exclusive selfing. Some of the conclusions drawn by Bertault and colleagues were then challenged by subsequent studies based on SSR (single sequence repeats) markers. Murat et al. (2004) showed a significant genetic differentiation between European T. melanosporum populations, while Rubini et al. (2005) and Riccioni et al. (2008) reported on the occurrence of outcrossing both in $T$. magnatum and T. melanosporum, respectively. As such, the SSR-assisted screening of the gleba and the pool of spores recovered from single T. magnatum and T. melanosporum fruiting bodies showed the presence of additional alleles in the asci with respect to the corresponding gleba in many of the samples analysed (Paolocci et al. 2006; Riccioni et al. 2008). As a result, this evidence not only undermined the hypothesis of strict selfing but also prompted the authors to argue that the gleba of truffles is largely made up of haploid hyphae of uniparental origin.

The conclusive evidence that T. melanosporum is not homothallic but an obligate outcrossing (heterothallic) fungus was proved by studying the structure and organization of the mating type genes in its genome (Martin et al. 2010, 2012). Ascomycetes usually exhibit two mating types, Mat1-1 and Mat1-2, two non-allelic sequences called idiomorphs (Coppin et al. 1997; Debuchy et al. 2010). They encode transcriptional factors that play a role both in the recognition between strains of different mating types and during meiosis, by controlling the production of pheromones and their receptors (Coppin et al. 1997). In homothallic Ascomycetes, both Mat genes are present in each strain. Conversely, in heterothallic fungi the two Mat genes are never present in the same strain, as it is the case in those of T. melanosporum (Martin et al. 2010; Rubini et al. 2011a).

\subsection{Tuber ectomycorrhizas are formed by haploid mycelium}

SSR markers were also used to determine the identity and ploidy level of T. magnatum ectomycorrhizas through the controlled inoculation of the host plant with SSR-genotyped sporal pools (Paolocci et al. 2006). These analyses provided direct evidence that $T$. magnatum ectomycorrhizas originate from primary haploid mycelium. After germination, the meiotic ascospores produce haploid mycelium, which colonizes host root tips, forming ectomycorrhizas. The same process is involved in T. melanosporum life cycle (Rubini et al. 2011b) and possibly in all species of the genus Tuber. Particularly relevant is the fact that each plant can be simultaneously colonized by different haploid mycelia, but the resulting ectomycorrhizas remain spatially separated on the root apparatus. Similarly, the presence of haploid ectomycorrhizas as well as evidence of a spatial separation between ectomycorrhizas from different fungal strains were then observed on host plants from open-field conditions (Rubini et al. 2011b; Murat et al. 2013). It has been hypothesized that cell surface factors might act at the pre-fusion level to prevent the formation of anastomosis between strains and, consequently, to maintain the genetic integrity of each strain during vegetative growth (Paolocci et al. 2006; Iotti et al. 2012).

In contrast to what is generally observed to occur in symbiotic Basidiomycetes, these data support the argument that the mycorrhizas of symbiotic Ascomycetes are only formed by primary mycelium and, in turn, that the life cycle of symbiotic Ascomycetes is prevalently haploid.

\subsection{T. melanosporum strains of opposite mating types compete for persistence on host plants}

Rubini et al. (2011b) found only one T. melanosporum strain per productive trees when ectomycorrhizas were randomly collected around trees from a natural stand. However, while monitoring the fate of fungal strains on artificially inoculated plants the same authors found that 6 months after inoculation with T. melanosporum ascospores, almost all of the seedlings (11 of 12) had ectomycorrhizas of both mating types, while 18 months after inoculation, 7 of 12 of these seedlings had only one mating type. Linde and Selmes (2012) analysed 85 2 -year-old seedlings from several Australian nurseries. All of these 2-year-old seedlings displayed ectomycorrhizas of both mating types. Thus, at the mycorrhizal level, within 2 years after inoculation, the competition appears to be very weak between the two mating types. Would this be the case for artificially inoculated seedlings transplanted to field conditions? Observations made in Australia by Linde and Selmes (2012) on T. melanosporum plantations set up between 2003 and 2007 showed that out of 16 productive trees, 8 displayed only one mating type while on the remaining 8 plants, ectomycorrhizas of both mating types were present, with slightly irregular distribution. Murat et al. (2013) compared two older plantations: one in Italy (Montemartano, Q. pubescens and Quercus ilex planted in 1995) and one in France (Rollainville, C. avellana, planted in 1991). In both orchards, in large soil patches (up to $15 \mathrm{~m}^{2}$ ), all of the T. melanosporum mycorrhizas displayed the same mating type, but not the same genets as proved by SSR-assisted genotyping of individual mycorrhizal root tips. From these different studies, we can conclude that competition between strains harbouring opposite mating types begins roughly 2 years after mycorrhizal establishment. Ten years after field transplantation, this strong competition leads to the complete exclusion of mycorrhizas of one mating type by mycorrhizas of the other. Consequently, ectomycorrhizas of opposite mating type tend to be spatially confined in separate areas of the truffle fields to form soil patches containing only one of the two mating types. Rubini et al. (2014) recently reviewed the practical implications related to competition between strains of opposite mating types. 


\subsection{Sexual reproduction overtakes vegetative propagation}

As for the majority of ectomycorrhizal fungi (Bonello et al. 1998; Douhan et al. 2011), the genetic structure of T. melanosporum in orchard results from a trade-off that takes place between the vegetative propagation of ectomycorrhizas along the roots and the formation of new ectomycorrhizas following ascospore germination. In T. melanosporum orchards, genets that persist for several years and genets detected only once have both been found. The former are less common and are likely to spread via vegetative growth, the latter make up the majority and likely derive from ascospore germination (Murat et al. 2013). In these truffle orchards, gene flow occurs mainly between closely situated genets (some metres) and less frequently between more distantly spaced genets (more than $90 \mathrm{~m}$ ) (Murat et al. 2013).

3.5 The maternal tissue of the ascocarps shares the same genotype of nearby ectomycorrhizas

Rubini et al. (2011b) were the first to observe corresponding genetic profiles between the maternal tissue of T. melanosporum ascocarps and nearby ectomycorrhizas. These similarities, later confirmed by Murat et al. (2013), were observed in other ectomycorrhizal fungi (Guidot et al. 2001; Zhou et al. 2001; Hirose et al. 2004; Lian et al. 2006), which is consistent with the role of ectomycorrhizas in feeding the nascent fruiting bodies (see below).

3.6 Ascocarp development depends on carbon allocation by the host and can take several months

Measuring some micrograms at its birth, the developing ascocarp can reach 50 to $100 \mathrm{~g}$ or more at the end of the maturation process. It was claimed for a long time that truffle ascocarps might be able to use dead host tissues or soil organic matter as carbon sources through a saprophytic process and that they became very early independent from the ectomycorrhizas (Callot 1999). Using a ${ }^{13} \mathrm{C}$ pulse-labelling technique, Le Tacon et al. (2013) demonstrated, under field conditions, that Tuber ascocarps are dependent on their hosts throughout their development. Tuber mycorrhizas provide a slow, but dominant pathway for carbon flux from trees to ascocarps.

The growth and development of T. melanosporum ascocarps take several weeks/months and require carbon stored in the host tree because they occurred after leaf fall (Le Tacon et al. 2013). This is different to the ectomycorhizal Basidiomycetes, which produce fruiting bodies within a few days by using recently assimilated carbon from the host (Teramoto et al. 2012). Initiation of black truffle ascocarps begins in May or June. Mature ascocarps are harvested from November until March of the following calendar year.

\section{Remaining unanswered questions}

4.1 The exclusion of one mating type by the opposite one and the structure and origin of gametes

\subsubsection{How to explain the exclusion of one mating type by its opposite in ectomycorrhizas?}

The exclusion of one mating type by the opposite one in ectomycorrhizas could be explained by the expression of genes linked to the Mat locus or by the Mat locus itself. In several Ascomycetes (Neurospora crassa Shear \& B.O. Dodge, Sordaria brevicollis L.S. Olive \& Fantini, Ascobolus stercorarius (Bull.) J. Schröt.), the Mat locus is one of the loci controlling vegetative incompatibility (Glass et al. 2000; Shiu and Glass 1999). Vegetative incompatibility results in the formation of a barrier system through cell-surface or extracellular factors causing cell death resulting from plasmogamy between non-compatible fungal strains. Anastomoses have never been observed between hyphae of different T. melanosporum strains grown under controlled conditions, but have frequently been observed between hyphae of the same strain (Iotti et al. 2012). Selosse et al. (2013) made the hypothesis that vegetative incompatibility could explain the exclusion of one mating type by the other from the same host plant.

Exclusion is linked to competition and the question is how two mycelia of different mating types compete in forming ectomycorrhizas. This exclusion could be due to the release of diffusible signals or derived as a consequence of physical contact between ectomycorrhizas of different mating types. One explanation could be that, under specific environmental conditions and/or developmental stages of mycorrhizas, the Mat1-1 mycelium encodes an extracellular compound toxic for the Mat1-2 mycelium and vice versa. Rizwana and Powell (1995) found that in Cryphonectria parasitica (Murrill) M.E. Barr vic1 and vic2 heterokaryon, the incompatibility function can be partially eliminated in protoplasts, suggesting that cell surface molecules might be involved. Extracellular compounds diffused by ectomycorrhizas in the soil nearby may inhibit the growth of soil mycelia of the opposite mating type. Additionally, the effect of hypothetical extracellular compounds should be confined to ectomycorrhizal stage only as in vitro cultivated mycelia of opposite mating types do not show any polarized growth or reciprocal inhibition (Iotti et al. 2012). An alternative explanation is that physical contact between mycorrhizas of opposite mating types determines the onset of competition. However, as discussed earlier, at the mycorrhizal level, it is likely that there are mechanisms operating to prevent contact between strains to preserve their integrity, regardless of their allelic configuration at the Mat locus.

The environmental and clinical predominance of a given mating type over the other occurs in different outcrossing 
fungi. Lin et al. (2005) demonstrated that a human pathogen Basidiomycete, Cryptococcus neoformans (San Felice) Vuill. can also reproduce through monokaryotic fruiting. Monokaryotic fruiting could occur through selfdiploidization or cell-cell fusion of genetically distinct partners of a like mating type. This process explains why one mating, usually the $\alpha$ type, can predominate on the other one. This mechanism is unlikely to occur in T. melanosporum fields. As such, for truffles harvested in areas where a single mating type was present, ascospores bearing the opposite mating type were consistently observed to be present.

In summary, we cannot currently provide a definitive explanation for either the mechanistic determinants or on the biological implications underlying competition between ectomycorrhizas of different mating types. We have simply noted that competition between mating partners seems to be counterintuitive to sexual propagation in heterothallic organisms (Rubini et al. 2014). Further, it is still unknown whether or not the host plant is somehow involved in this exclusion or competition. According to observations made in the Rollainville orchard (Lorraine, France), a single tree can be colonized by two continuous patches, which seems to mean that the host is not directly involved in the competition between the two mating types at the mycorrhizal level (Fig. 1).

\subsubsection{Does the exclusion of one mating type by its opposite exist in soils?}

T. melanosporum can exist in soils in several forms such as ascospores, germinating ascospores, free-living mycelium, emanating hyphae from mycorrhizas, remainders of ascocarps and ectomycorrhizas, or other forms like mitospores or conidiospores. There are very few studies which address the distribution of Tuber mating types in soils. Soil DNA kits used for these studies do not allow for ascospore DNA extraction, but do allow for DNA extraction from other forms of fungal material (Parladé et al. 2013). Results obtained by Murat et al. (2013) in two truffle orchards (Montemartano and Rollainville) were found to be site-dependent. In Montemartano, all soil samples exhibited a single mating type, either Mat 1-1 or Mat 1-2, and this was shared with the nearby T. melanosporum ectomycorrhizas. In Rollainville, part of the soil samples exhibited fungal material harbouring the Mat1-2 idiomorph, even next to sites in which the ectomycorrhizas were formed by Mat1-1 strains; many soil samples displayed both mating types, other soil samples exhibited only the presence of only Mat1-1. The presence of both mating types was also detected in soil samples collected on productive patches of a naturally grown $T$. melanosporum field (Rubini et al. 2011b). From these results, evidence emerged that both mating types can be found in the soil, even when only one is present on the ectomycorrhizas located nearby. When only one mating type is detected in soil samples, it corresponds to the dominant mating type of the ectomycorrhizas. Inefficient extraction and amplification of the soil DNA could explain the fact that both mating types are not always identified in soil samples. It is therefore conceivable that fungal strains of both mating types need to coexist in productive soil, at least at specific temporal stages (i.e. in spring when fertilization is thought to occur, Le Tacon et al. 2014) even if only one mating type is present on the ectomycorrhizas of productive trees. It is likewise plausible that competition between the two mating types, which is elevated at the ectomycorrhizal level, will not occur if one or both mating partners do not establish functional ectomycorrhizas with the host.
Fig. 1 Rollainville

T. melanosporum orchard

(France). Spatial distribution of the maternal mating types of the ascocarps around the hazel trees F10 and F11 and the oak E10 in 2010-2011 and 2011-2012. The orange line delimits the ascocarps of maternal Mat 1-1 and the green line the ascocarps of maternal Mat 1-2

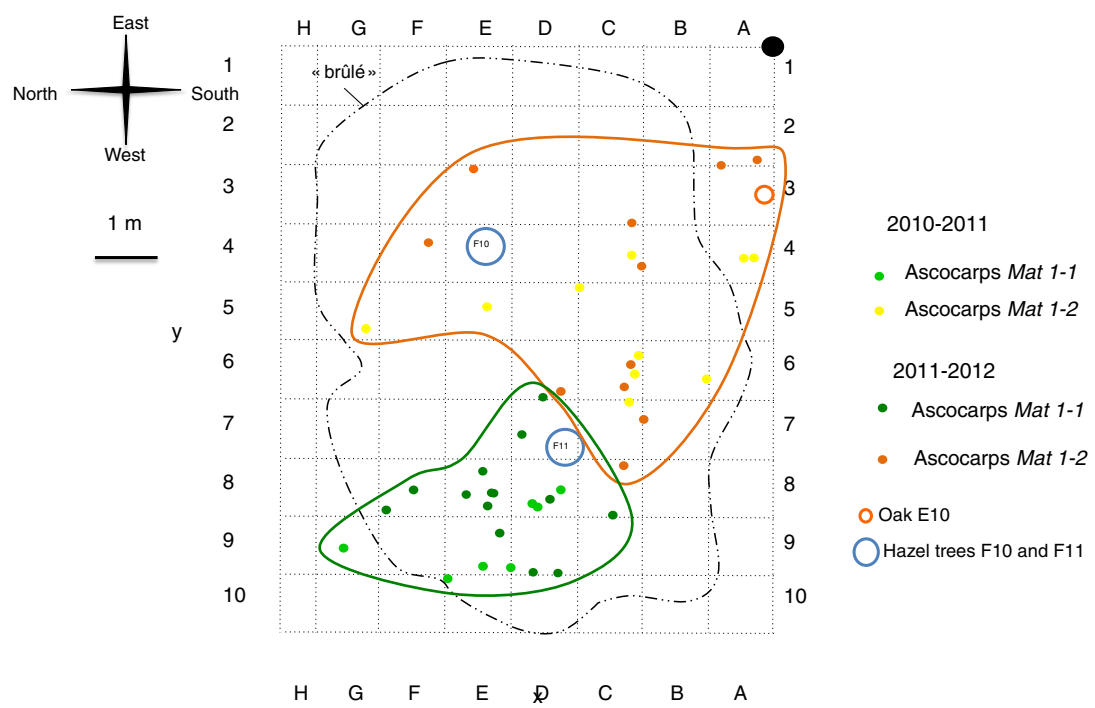

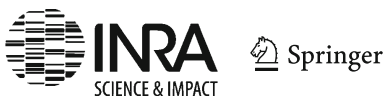




\subsubsection{What are the gametes?}

As Tuber species belong to the Pezizales, their sexual cycle cannot differ much from that of the majority of the other species belonging to this order. In Pezizales, the ascogonium, or the female structure, develops from haploid mycelium of one mating type, often with an apical receptor called the trichogyne. The ascogonium can be naked or it can be enclosed in mycelium. The same haploid mycelium can form the antheridium, which produces the male elements (antherozoids). In heterothallic Ascomycetes, the female and male elements developed from this hermaphrodite haploid mycelium, harbouring the same mating type, are not able to mate (Nauta and Hoekstra 1992).

Therefore, we can assume that the haploid T. melanosporum mycelium colonizing host roots is equally capable of giving birth both to antheridia, producing male gametes (antherozoids), and ascogonia, producing female gametes. Tuber ascogonia have been very rarely observed. Parguey-Leduc and Janex-Favre published two pictures of a T. melanosporum ascogonium with its trichogyne and its ascogonial filament (in Callot 1999). The fact that the maternal tissue of the T. melanosporum ascocarps always shares the same mating type and genetic profile of the nearby ectomycorrhizas (Rubini et al. 2011b; Murat et al. 2013) supports the assumption that it originates from the strain that forms both ascogonium and the nearby mycorrhiza. Ascogonium fertilization requires the entry of a male element of the opposite mating type.

The male elements have not yet been identified in the genus Tuber. The fact that these male structures have never been found could mean that the male function may be fulfilled by any haploid tissues, such as haploid mycelium issued from ascospores, or mitotic conidia, as suggested by Rubini et al. (2011b). It has long been understood that for several Neurospora species, mitotic conidia are able to act as spermatia (Dodge 1932). Many Ascomycetes form asexual spores (conidia) that serve as vegetative elements or as male parents (Nelson 1996). Urban et al. (2004) described in soils, where Tuber borchii Vittad. and Tuber oligospermum (Tul. \& C. Tul.) Trappe ascocarps were present, the existence of anamorph structures producing mitotic conidia or conidiospores. According to the authors, these conidia could possibly play a role in the vegetative propagation of these two Tuber species. Nevertheless, it is possible that these conidia are linked with the male apparatus and, as such, could play a role in the sexual reproduction as suggested by Healy et al. (2012). According to these authors, Pezizales mitospores, including Tuber mitospores, failed to form ectomycorrhizas on seedlings of different species, consistent with the hypothesized role of spermatia. However, the question of whether conidia of Tuber species act as spermatia or agents of dispersion, or both, remains unanswered. Another question concerns the origin of these conidiospores. Do they arise directly from haploid mycelium resulting from germinating ascospores in the soil or do they arise from antheridia previously formed from haploid ectomycorrhizas?

Mitospores or conidiospores described by Urban et al. on T. borchii and T. oligospermum and later by Healy et al. on several other Tuber species have not yet been found in T. melanosporum, but we can assume that they exist. If mitospores are important for Tuber sexual reproduction, as suggested by Healy et al. (2012), we can make the assumption that climatic conditions could be critical for initiation of sexual reproduction throughout the development of the mitospores, expected to occur in late winter or spring of the year $n-1$. Le Tacon et al. (2014) found a significant positive correlation between January rainfall of the year $n-1$ and T. melanosporum production in France, which could further support this hypothesis.

\subsubsection{How do male gametes survive?}

A single tree can produce ascocarps during several consecutive years with very little shift in the location of the fruiting bodies from 1 year to the next (Murat et al. 2013). Moreover, ascocarps are not found more frequently where two patches border one another (Fig. 1), although their chances for mating are expected to be higher in the zone of contact between two mycorrhizal patches of opposite mating types. Both the female partner and the male partner need to have established a stable presence over several years in the same soil patch. The male elements could survive in the soil several years after their transfer from one patch to another by vegetative and saprophytic means. However, it is difficult to believe that the male elements can survive in the soil several years without establishing a functional link with a carbon supplying partner. It is in fact largely accepted that ectomycorrhizal fungi, including T. melanosporum (see below), do not rely on dead organic matter as a carbon source (Treseder et al. 2007; Le Tacon et al. 2013). Thus, an alternative explanation could be that the male partner can survive in association with nonclassical hosts. Along this line of reasoning, we know that truffle mycelium can be hosted by species, which form ectomycorrhizas like those of the genus Cistus (Comandini et al. 2006). It can be also hosted by orchids without forming a classical ectomycorrhizas structure (Selosse et al. 1999) or hosted by herbaceous plants, which could lodge the mycelium without forming mycorrhizas.

Related to this concern, Gryndler et al. (2014) recently reported on the association of $T$. aestivum mycelia with roots of non-host trees and herbaceous plants. Regardless of the modes of survival of the male elements present in the soil, each of the two mating partners needs vegetative growth toward the other to achieve the process of fecundation. 


\subsubsection{How do gametes of opposite mating types meet?}

To complete its life cycle, a heterothallic ascomycete needs to produce an ascogonium cell that is fertilized, through the trichogyne, by a male element produced by a strain of the opposite mating type. The recognition between cells of opposite mating types is mediated by diffusible pheromones that are produced in a mating type-specific manner. In the T. melanosporum genome, several key genes, related to biosynthesis and perception of pheromones, have been identified (Martin et al. 2010; Rubini et al. 2012). To mate, the two T. melanosporum mating partners have to be close enough to one another to sense and be perceived via the pheromone receptor system establishing their reciprocal presence (Rubini et al. 2012). The transfer of fertilizing agents, such as detached cells, spores, mitospores and so on, to ectomycorrhizas of the opposite mating type could be favoured by animals, such as worms, insects, small mammals or wild boars, or by the tools used for orchard management. However, the close proximity of two potential mating partners is not sufficient to engage the fertilization process. Linde and Selmes (2012) showed in Australian truffle orchards that about $40 \%$ of unproductive trees sustain mycorrhizas of both mating types. Factors other than the close vicinity of compatible gametes are thus necessary for fertilization to take place. For example, a cold stress factor could be necessary (Zampieri et al. 2011). Understanding the factors that switch the pheromone signal transduction pathway in T. melanosporum strains of different mating types may help us to elucidate the biotic and abiotic determinants underlying the entry of this fungus into the sexual phase.

\subsection{Post fertilization events and the complexity of truffle development}

\subsubsection{When do plasmogamy and karyogamy take place?}

In Pezizales, after being trapped by the trichogyne, the antherozoid can remain dormant or can fuse rapidly with ascogonium cells by plasmogamy. In T. melanosporum, we do not know if plasmogamy takes place immediately after fertilization. On the one hand, as highlighted earlier, molecular data has shown that the gleba is a haploid and maternal tissue like the peridium, whose cells prompt the walls to thicken. On the other hand, each haploid ascospore, resulting from the karyogamy between the two partners followed by meiosis, bears either the Mat1-1 or Mat1-2 gene (Rubini et al. 2011a). The dikaryotic cells of maternal and paternal origin are difficult to see and molecular approaches have thus far failed to detect dikaryotic cells of maternal and paternal origin at any stage of truffle development.

We can therefore infer the genomic configuration of the male partner only by analysing the spores. These results have substantiated the view that the fertilization process, and the resulting dikaryotic phase in Tuber spp., could be spatially and/or temporally confined to the very early stages of ascocarp development (Rubini et al. 2007). To date, the reproductive phases downstream of fertilization have yet to be traced molecularly. However, inferences about the reproductive biology of truffles can be made on the basis of morphological and microscopic analyses. By observing a cross section of a T. melanosporum truffle, it clearly emerges that white and black elements are present: the former have traditionally been regarded as sterile veins the latter as fertile veins as the spores localized therein. The sterile veins are therefore thought to be made by the maternal tissue and will remain white during the whole process of maturation, while the fertile veins should contain the fertile ascogenous, and thus heterokaryotic tissue (Fig. 2). These fertile veins which also are white in non-mature ascocarps become brown and then black when the spores are mature (Figs. 3 and 4). However, before they measure $1 \mathrm{~mm}$ in diameter, no ascogenous tissue can be microscopically detected in the young ascocarps. Only maternal tissue can be observed. Moving from these microscopic observations, it could be then argued that plasmogamy occurs several weeks after fertilization when the first fertile veins appear.

Conversely, once they have reached a diameter of about $1 \mathrm{~mm}$, the ascocarps start to exhibit white fertile veins in which plasmogamy have occurred, but not karyogamy. Indeed, dikaryotic cells can be observed in this ascogenous tissue (Fig. 5a). During ascocarp development, ascogenous cells do not give rise to croziers like in many Pezizales. They continuously give birth to specialized cells, the ascus mother cells (Fig. 5b), in which karyogamy and then almost immediately meiosis occurs (Fig. 5c). The meiosis is followed by one (Fig. 5d) or more postmeiotic mitoses, to give birth to four

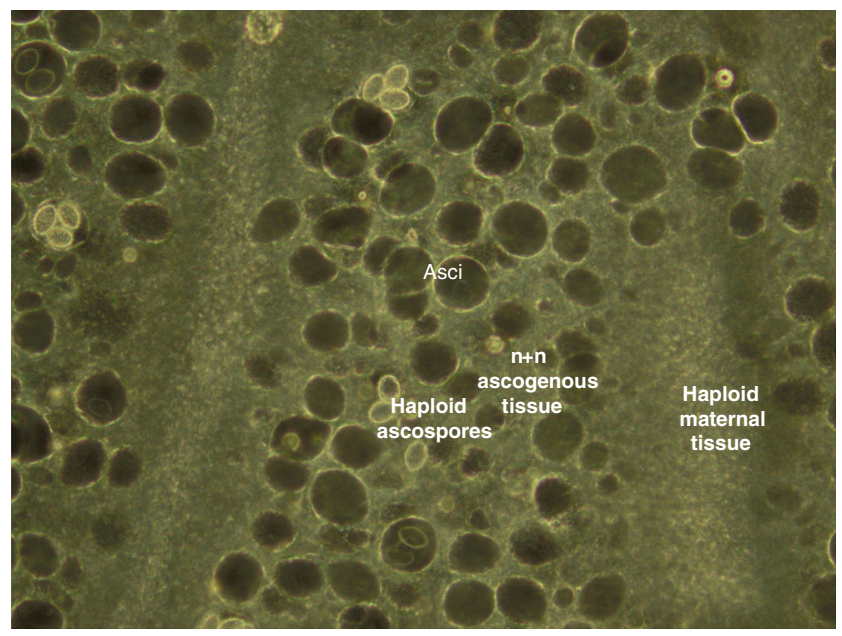

Fig. 2 Haploid maternal tissue and ascogenous tissue with asci and ascospores in a semi-mature T. melanosporum ascocarp (light microscope, 30- $\mu \mathrm{m}$ thick cut of Tuber melanosporum ascocarp without staining) 


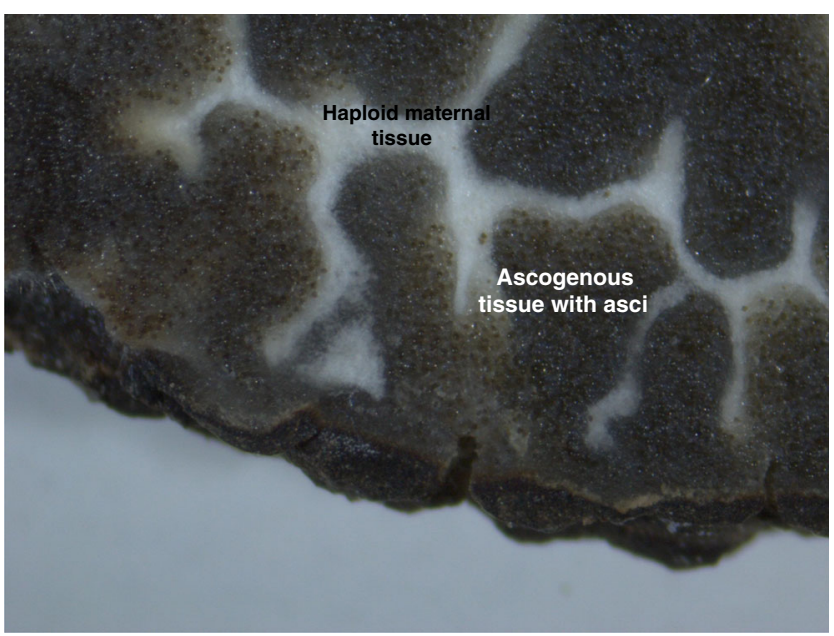

Fig. 3 Haploid maternal tissue and ascogenous tissue of a mature T. melanosporum ascocarp (dissecting microscope, $4 \times$ magnification)

(or more) plurinucleate ascospores (Fig. 5e), whose walls are formed by a double-membrane system inside the ascus mother cell. In the near future, we expect that it will be possible to dissect and genotype each single structure differentiated within the ascocarp during its development to provide conclusive evidence in support of our model (Fig. 6).

\subsubsection{Why does it take several years for ascocarp production to begin after host plantation?}

Seedlings harbouring T. melanosporum ectomycorrhizas never produce ascocarps during the 2 years of the nursery phase. Ascocarps are usually produced 5 to 20 years after plantation. Thus, T. melanosporum cannot be considered an early-stage ectomycorrhizal fungus like Laccaria bicolor (Maire) P.D. Orton, Laccaria laccata (Scop.) Cooke, Scleroderma citrinum Pers., Paxillus involutus (Batsch) Fr. and some other

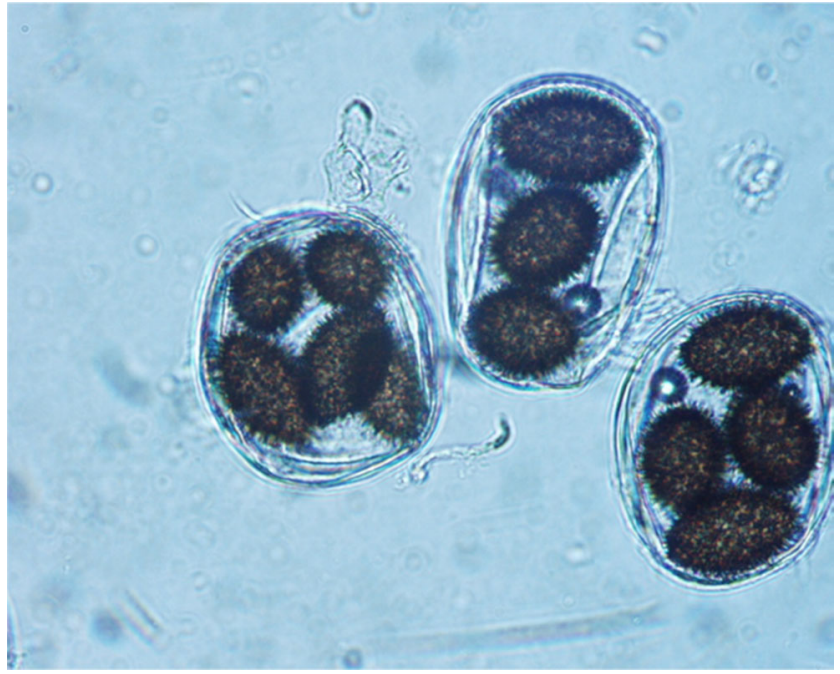

Fig. 4 T. melanosporum black haploid mature ascospores in their asci (light microscope)
Basidiomycetes which fructify 1 or 2 years after the establishment of the symbiosis in the nursery (Buée et al. 2011). T. melanosporum seems to belong to middle-stage ectomycorrhizal fungi which fructify several years after the establishment of the stand. Nevertheless, Tuber species do not all behave in the same way. Fassi and Fontana (1967, 1969) obtained ascocarps of T. maculatum associated with P. strobus in the second year after mycorrhizal establishment in containers, and the following year by transplantation to new pots.

We have not yet identified the factors involved in the induction of the fructification of early- or late-stage ectomycorrhizal fungi. Seedlings artificially inoculated with T. melanosporum ascospores exhibit ectomycorrhizas of both mating types (Rubini et al. 2011b). Thus, the absence of one mating type cannot explain the absence of fructification at this step. As reported above, after field transplantation, strong competition occurs between ectomycorrhizas of different mating types, which leads to the formation of patches where only one mating type is present. These patches could remain sterile if no mycelia or gametes of the opposite mating type are present in the soil. However, as pointed out earlier, close proximity of male and female gametes of opposite mating types is not sufficient to engage the fertilization process. Unknown factors, which remained to be discovered, are necessary for ascocarp initiation. Courty et al. (2010) demonstrated that poplar clones differentially control gene expression of their fungal associates. Tuber fructification could also be under the genetic control of the host. For the moment, no evidence exists to demonstrate such a mechanism.

\subsection{Does nitrogen fixation occur in T. melanosporum ascocarps?}

Barbieri et al. (2010) detected the expression of the nitrogenase gene nifH from Bradyrhizobia in T. magnatum ascocarps; they found that the nitrogenase activity assessed by acetylene reduction was comparable to that of young legume nodules. Antony-Babu et al. (2014) proved that T. melanosporum ascocarps are extensively colonized by Bradyrhizobiaceae. They detected the nif genes in the ascocarps, although these genes were not related to Bradyrhizobiaceae but to unknown bacteria, suggesting the involvement of other $\mathrm{N}_{2}$-fixing bacteria. Despite the presence of these bacterial nif genes inside the T. melanosporum ascocarp, $\mathrm{N}_{2}$ fixation was neither detected by acetylene reduction assay nor by the use of ${ }^{15} \mathrm{~N}_{2}$ gas in immature and mature ascocarps collected in two orchards in France (Deveau et al., unpublished data). Therefore, despite a similar taxonomic community structure, the bacterial community within the ascocarps of T. magnatum and T. melanosporum would appear 
Fig. 5 Dikaryotic tissue, karyogamy, meiosis and ascospore differentiation in nonmature ascogenous tissue of

T. melanosporum ascocarps (a, b dilacerated ascocarp stained with $1 \mu \mathrm{M}$ DAPI and Calcofluor White Stain (Invitrogen) imaged with Zeiss LSM 780 confocal microscope at $40 \times$ magnification. c-e 30- $\mu$ m thick cut of

T. melanosporum ascocarp stained with $1 \mu \mathrm{M}$ DAPI and observed under UV fluorescence with an Olympus BX42TF epifluorescence microscope at $63 \times$ magnification). a

Ascogenous tissue with dikaryotic cells. b Young ascus mother cells with two nuclei and then one nucleus after karyogamy. c Meiose in ascus mother cells. d Individualization of cytoplasm and cell wall around the two haploid nuclei just after the meiotic division in ascus mother cells. e Ascogenous tissue with plurinucleate ascospores in ascus mother cell

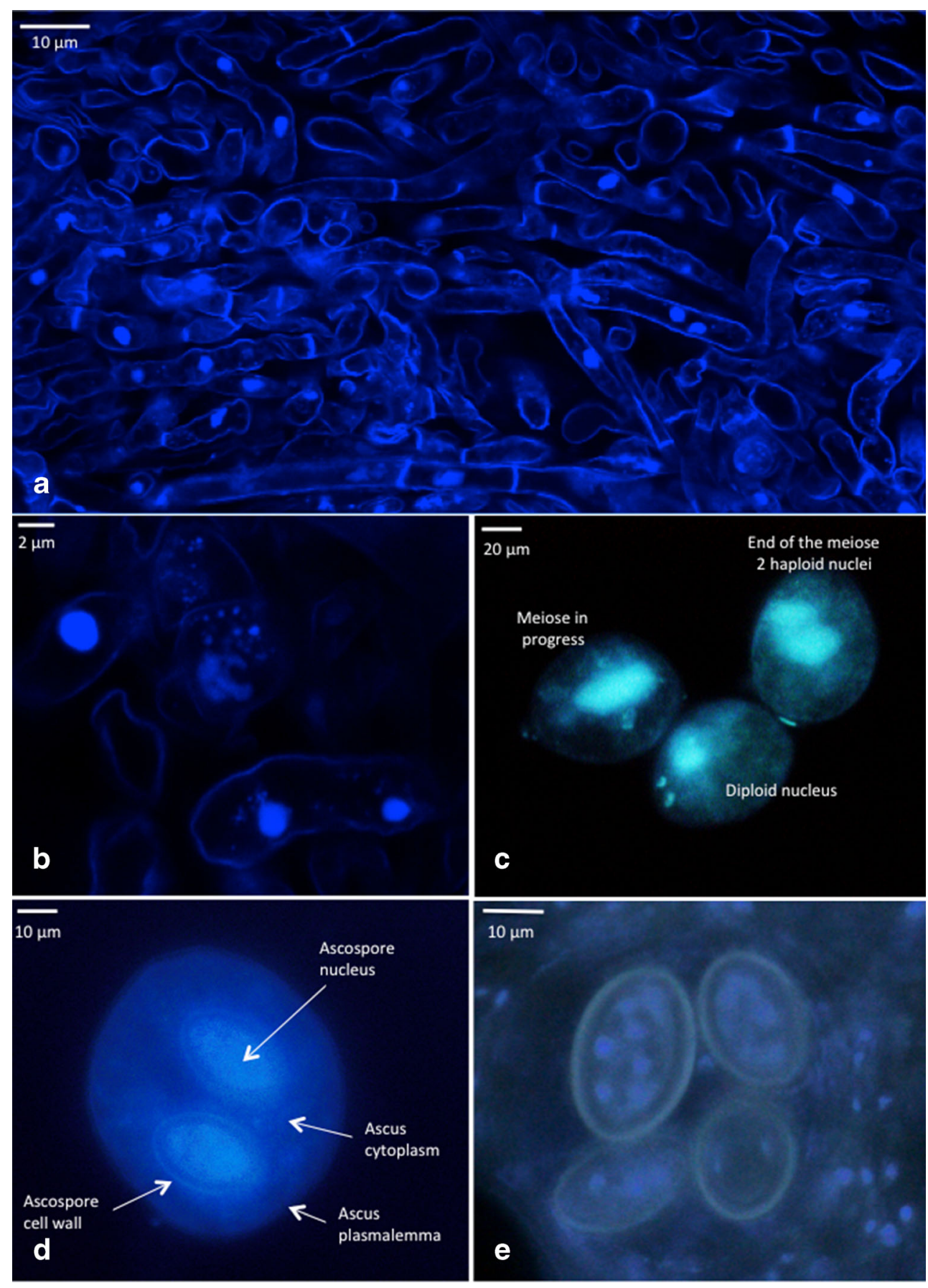

to differ at the functional level: bacteria would not participate at all or would participate very little in the nitrogen nutrition of T. melanosporum ascocarp in contrast to what occurs in T. magnatum. However, more extensive analysis on multiple orchards will be necessary to definitively determine whether or not $T$. melanosporum ascocarps possess nitrogen fixation abilities via the bacteria inhabiting the gleba. Indeed, it is possible that this activity is expressed only in specific conditions that remain to be discovered.
4.4 The link between ascocarps and ectomycorrhizas has not yet been found

The existence of a physiological connection between ectomycorrhizas and ascocarps and the allocation of carbon by the host to truffles throughout their development has been established (Le Tacon et al. 2013). However, this physical link between truffle ectomycorrhizas and ascocarps has never been directly observed. This is because it is not possible to grow 
Fig. 6 Hypothetical life cycle of T. melanosporum

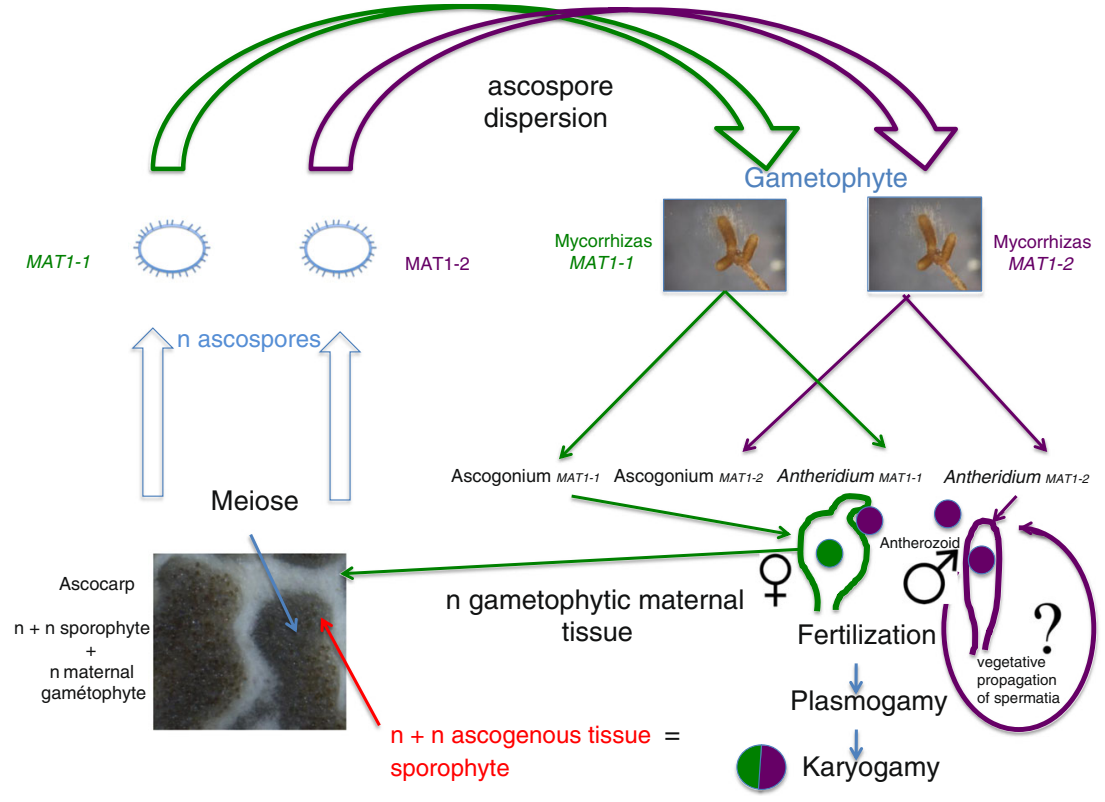

T. melanosporum ascocarps in controlled conditions, and harvesting ascocarps by digging is disruptive and damaging to this very fragile connection. Observing ascocarps in controlled conditions will be essential to describe this fragile physical link.

\section{Conclusions}

In recent years, major questions concerning the life cycle of T. melanosporum have been answered: characterization of the two mating types, highlighting of heterothallism, prevalence of sexual reproduction on vegetative propagation, exclusion of one mating type by the other one on ectomycorrhizas and dependency of ascocarps from their host for carbon allocation.

However, many aspects of $T$. melanosporum life cycle remain unsolved. One of these pending questions is related to mitotic spores. They have been discovered in other Tuber species but not in T. melanosporum. However, several indicators support both their existence and their role as spermatia. We make the assumption that mycelia of both mating types present in the soil of trees producing truffles are able to survive in the soil for several years by vegetative propagation or in association with orchids, Cistus or any adventitious plants. These mycelia can then produce spermatia to ensure sexual propagation. In turn, spermatia themselves could survive in the soil for extended periods. This is the most plausible scenario to explain the stability of ascocarp production in patches where one mating type has been excluded on ectomycorrhizas.

While Tuber ascogonia have not been sufficiently described, their existence is more than probable, which would explain the unbalance between maternal and paternal tissues in young ascocarps. We have yet to determine whether spermatia are mitospores or antheridia.

Many other aspects of the T. melanosporum life cycle remain unsolved: competitive mechanisms between ectomycorrhizal mating types, factors involved in ascocarp initiation, the nature of the link between ascocarps and mycorrhizas, and atmospheric nitrogen fixation. A comprehensive understanding of these aspects of the T. melanosporum life cycle would lead to a better management of black truffle orchards.

Acknowledgements We thank the Regional Council of Lorraine, which has contributed to finance the facilities of the Lorraine INRA Centre. We would also like to thank the two anonymous reviewers for their interest in our work and for their comments or suggestions, which allowed us to greatly improve the first version of this manuscript. We are thankful to Aimee Orsini for having corrected the English of this article.

Funding A part of the results described in this review were funded by the SYSTRUF programme (an integrated approach for sustainable management of ecosystems producing black truffle, Tuber melanosporum) financed by the French ANR (Agence Nationale de la Recherche; programme SYSTERRA, ANR-09-STRA-10-02) and also supported by a grant overseen by the French National Research Agency (ANR) as part of the "Investissements d'Avenir" programme (ANR-11-LABX-0002-01, Lab of Excellence ARBRE).

\section{Glossary}

Antheridium

Male structure producing male gametes.

Antherozoids Male gametes produced by the antheridium.

Ascocarp Fruiting body of fungi from the Ascomycota phylum in which asci are formed. 
Ascogenous tissue $\mathrm{n}+\mathrm{n}$ tissue formed from the ascogonium after fertilization by antherozoids. After plasmogamy, the cells are dikaryotic with one nucleus coming from the female element and the other from the male element.

Ascogonium

Ascospores

Ascus

Haploid

heterothallic

Homothallic

Karyogamy

Mating type

Plasmogamy

Pseudohomothallic

Spermatia

\section{References}

Antony-Babu S, Deveau A, Van Nostrand JD, Zhou J, Le Tacon F, Robin C, Frey-Klett P, Uroz S (2014) Black truffle-associated bacterial communities during the development and maturation of Tuber melanosporum ascocarps and putative functional roles. Environ Microbiol 16:2831-47. doi:10.1111/1462-2920.12294

Barbieri E, Ceccaroli P, Saltarelli R, Guidi C, Potenza L, Basaglia M, Fontana F, Baldan E, Casella S, Ryahi O, Zambonelli A, Stocchi V (2010) New evidence for nitrogen fixation within the Italian white truffle Tuber magnatum. Fungal Biology 114:936-942

Bertault G, Raymond M, Berthomieu A, Callot G, Fernandez D (1998) Trifling variation in truffles. Nature 394:734. doi:10.1038/29428

Bertault G, Rousset F, Fernandez D, Berthomieu A, Hochberg ME, Callot G, Raymond M (2001) Population genetics and dynamics of the black truffle in a man-made truffle field. Heredity $86: 451-458$
Bonello P, Bruns TD, Gardes M (1998) Genetic structure of a natural population of the ectomycorrhizal fungus Suillus pungens. New Phytol 138:533-54

Bonito G, Smith ME, Nowak M, Healy RA, Guevara G, Cázares E, Kinoshita A, Nouhra ER, Domínguez LS, Tedersoo L, Murat C, Wang Y, Moreno BA, Pfister DH, Nara K, Zambonelli A, Trappe JM, Vilgalys R (2013) Historical biogeography and diversification of truffles in the Tuberaceae and their newly identified southern hemisphere sister lineage. PLoS ONE 8:e52765. doi:10.1371/ journal.pone. 0052765

Buée M, Maurice JP, Zeller B, Andrianarisoa S, Ranger J, Courtecuisse R, Marçais B, Le Tacon F (2011) Influence of tree species on richness and diversity of epigeous fungal communities in a French temperate forest stand. Fungal Ecol 4:22-31

Callot G (1999) La Truffe, la Terre. la Vie. INRA Editions, Paris

Ceruti A, Fontana A, Nosenzo C (2003) European species of the genus Tuber. An historical revision. Museo Regionale di Scienze Naturali, Monographie XXXVII. Regione Piemonte, Torino

Chevalier G (1973) Synthèse axénique des mycorhizes de Tuber brumale Vitt.à partir de cultures pures du champignon. Ann Phytopathol 5: 163-182

Chevalier G, Desmas C (1977) Synthèse des mycorhizes de T. melanosporum avec Corylus avellana sur agar à partir de spores. Ann Phytopathol 9:531

Chevalier G, Grente E, Jet Pollacsek A (1973) Obtention de mycorhizes de différents Tuber par synthèse à partir de spores en conditions axéniques et gnotoxéniques. Ann Phytopathol 5:107-108

Comandini O, Contu M, Rinaldi AC (2006) An overview of Cistus ectomycorrhizal fungi. Mycorrhiza 16:381-395. doi:10.1007/ s00572-006-0047-8

Coppin E, Debuchy R, Arnaise S, Picard M (1997) Mating types and sexual development in filamentous ascomycetes. Microbiol Mol Biol Rev 61:411-428

Courty PE, Labbé J, Kohler A, Marçais B, Bastien C, Churin JL, Garbaye J, Le Tacon F (2010) Effect of poplar genotypes on mycorrhizal infection and secreted enzyme activities in mycorrhizal and nonmycorrhizal roots. J Exp Bot. doi:10.1093/jxb/erq274

Dangeard PA (1894) La Truffe. Recherches sur son développement, sa structure, sa reproduction sexuelle. Botaniste 4:63-87

Debuchy R, Berteaux-Lecellier V, Silar P (2010) Mating systems and sexual morphogenesis in Ascomycetes. In: Borkowich KA, Ebbole DJ (eds) Washington. ASM press, DC, USA, pp 501-535

Dereix de Laplane T (2010) Des truffes sauvages aux truffes cultivées en Loudunais.Mémoires de l'Académie des Sciences. Arts et BellesLettres de Touraine 23:215-241

Dodge BO (1932) The non-sexual and the sexual functions of microconidia of Neurospora. B Torrey Bot Club 347-360

Douhan GW, Vincenot L, Gryta H, Selosse MA (2011) Population genetics of ectomycorrhizal fungi: from current knowledge to emerging directions. Fungal Biology 115:569-597

Fassi B, Fontana A (1967) Sintesi micorrizica tra Pinus strobus e Tuber maculatum - I. Micorrize e sviluppo dei semenzali nel secondo anno. Allionia 13:177-186

Fassi B, Fontana A (1969) Sintesi micorrizica tra Pinus strobus e Tuber maculatum - II. Sviluppo dei semenzali trapiantati e produzione di ascocarpi. Allionia 15:117-119

Frank AB (1885) Uber die auf Wurzelsymbiose beruhende Ernährung gewisser Bäume durch unterirdische Pilze. Ber Dtsch Bot Ges 3: $128-145$

Glass NL, Jacobson DJ, Shiu PKT (2000) The genetics of hyphal fusion and vegetative incompatibility in filamentous ascomycete fungi. Ann Rev Genet 34:165-186

Grente J, Chevalier G, Pollacsek A (1972) La germination de l'ascospore de Tuber melanosporum et la synthèse sporale des mycorhizes. C R Ac Sc 275:743-746 
Gryndler M, Černá L, Bukovská P, Hršelová H, Jansa J (2014) Tuber aestivum association with non-host roots. Mycorrhiza 24:603-610

Guidot A, Debaud JC, Marmeisse R (2001) Correspondence between genet diversity and spatial distribution of above- and belowground populations of the ectomycorrhizal fungus Hebelomacylindrosporum. Mol Ecol 10:1121-1131

Healy RA, Smith ME, Bonito GM, Pfister DH, Ge ZW, Guevara GG, Williams G, Stafford K, Kumar L, Lee T, Hobart C, Trappe J, Vilgarys R, Mclaughlin DJ (2012) High diversity and widespread occurrence of mitotic spore mats in ectomycorrhizal Pezizales. Mol Ecol 22:1717-1732. doi:10.1111/mec.12135

Hirose D, Kikuchi J, Kanzaki N, Futai K (2004) Genet distribution of sporocarps and ectomycorrhizas of Suillus pictus in a Japanese white pine plantation. New Phytol 164:527-541

Iotti M, Rubini A, Tisserant E, Kohler A, Paolocci F, Zambonelli A (2012) Self/nonself recognition in Tuber melanosporum is not mediated by a heterokaryon incompatibility system. Fungal Biology 116:261-275

Jeandroz S, Murat C, Wang YJ, Bonfante P, Le Tacon F (2008) Molecular phylogeny and historical biogeography of the genus Tuber, the 'true truffles'. J Biogeogr 35:815-829. doi:10.1111/j.1365-2699.2007. 01851.x

Kües U, Martin F (2011) On the road to understanding truffles in the underground. Fungal Genet Biol Special Section: Tuber Genome 48:555-560

Lanfranco L, Arlorio M, Matteucci A, Bonfante P (1995) Truffles: their life cycle and molecular characterization. In: Stocchi V, Bonfante P, Nuti P (eds) Biotechnology of ectomycorrhizae. Molecular approach. Plenum Press, New York, NY, USA, pp 139-149

Le Tacon F, Zeller B, Plain C, Hossann C, Bréchet C, Robin C (2013) Carbon transfer from the host to Tuber melanosporum mycorrhizas and ascocarps followed using a $13 \mathrm{C}$ pulse-labeling technique. PLoS One 8:e64626

Le Tacon F, Marçais B, Courvoisier M, Murat C, Montpied P, Becker M (2014) Climatic variations explain annual fluctuations in French 'Périgord black truffle' wholesale markets but do not explain the decrease in 'black truffle' production over the last 48 years. Mycorrhiza, special issue on Truffles 24:115-125. doi:10.1007/ s00572-014-0568-5

Leisle JF, Klein KK (1996) Female fertility and mating type effects on effective population size and evolution in filamentous fungi. Genetics 144:557-5

Lian C, Narimatsu M, Nara K, Hogetsu T (2006) Tricholoma matsutake in a natural Pinus densiflora forest: correspondence between aboveand below-ground genets, association with multiple host trees and alteration of existing ectomycorrhizal communities. New Phytol $171: 825-36$

Lin X, Hull CM, Heitman J (2005) Sexual reproduction between partners of the same mating type in Cryptococcus neoformans. Nature 434: 1017-102. doi:10.1038/nature03448

Linde CC, Selmes H (2012) Genetic diversity and mating type distribution of Tuber melanosporum and their significance to truffle cultivation in artificially planted truffières in Australia. Appl Environ Microb 78:6534-6539

Martin F, Kohler A, Murat C, Balestrini R, Coutinho PM, Jaillon O, Montanini B, Morin E, Noel B, Percudani R, Porcel B, Rubini A, Amicucci A, Amselem J, Anthouard V, Arcioni S, Artiguenave F, Aury JM, Ballario P, Bolchi A, Brenna A, Brun A, Buée M, Cantarel B, Chevalier G, Couloux A, Da Silva C, Denoeud F, Duplessis S, Ghignone S, Hilselberger B, Iotti M, Marçais B, Mello A, Miranda M, Pacioni G, Quesneville H, Riccioni C, Ruotolo R, Splivallo R, Stocchi V, Tisserant E, Viscomi AR, Zambonelli A, Zampieri E, Henrissat B, Lebrun MH, Paolocci F, Bonfante P, Ottonello S, Wincker P (2010) Périgord black truffle genome uncovers evolutionary origins and mechanisms of symbiosis. Nature 464:10331038
Martin F, Murat C, Paolocci F, Rubini A, Riccioni C, Belfiori B, Arcioni S (2012) Molecular method for the identification of mating type genes of truffles species. European Patent Application EP2426215

Mattirolo O (1914) La tartuficoltura e il rimboschimento. Torino

Murat C, Díez J, Luis P, Delaruelle C, Dupré C, Chevalier G, Bonfante P, Martin F (2004) Polymorphism at the ribosomal DNA ITS and its relation to postglacial re-colonization routes of the Perigord truffle Tuber melanosporum. New Phytol 164:401-411

Murat C, Rubini A, Riccioni C, De la Varga H, Akroume E, Belfiori B, Guaragno M, Le Tacon F, Robin C, Halkett F, Martin F, Francesco Paolocci F (2013) Fine-scale spatial genetic structure of the black truffle (Tuber melanosporum) investigated with neutral microsatellites and functional mating type genes. New Phytol 199: 176-187

Nauta MJ, Hoekstra RF (1992) Evolution of reproductive systems in filamentous ascomycetes. II. Evolution of hermaphroditism and other reproductive strategies. Heredity 68:537-546

Nelson MA (1996) Mating systems in Ascomycetes: a romp in the sac. Trends Genet 12:69-74

Olivier JM, Savignac JC, Sourzat P (2012) Truffe et trufficulture. Périgueux, France, FANLAC Editions

Palenzona M (1969) Mycorrhizal synthesis between Tuber aestivum Vitt., Tuber brumale Vitt., Tuber melanosporum Vitt., and seedlings of Corylus avellana. Allionia 15:121-131

Paolocci F, Rubini A, Riccioni C, Arcioni S (2006) Reevaluation of the life cycle of Tuber magnatum. Appl Environ Microb 72:2390-2393

Parladé J, De la Varga H, De Miguel AM, Sáez R, Pera J (2013) Quantification of extraradical mycelium of Tuber melanosporum in soils from truffle orchards in northern Spain. Mycorrhiza 23: 99-106

Riccioni C, Belfiori B, Rubini A, Passeri V, Arcioni S, Paolocci F (2008) Tuber melanosporum outcrosses: analysis of the genetic diversity within and among its natural populations under this new scenario. New Phytol 180:466-478

Rizwana R, Powell WA (1995) Ultraviolet light-induced heterokaryon formation and parasexuality in Cryphonectria parasitica. Exp Mycol 19:48-60

Rubini A, Paolocci F, Riccioni C, Vendramin GG, Arcioni S (2005) Genetic and phylogeographic structures of the symbiotic fungus Tuber magnatum. Appl Environ Microb 71:6584-6589

Rubini A, Riccioni C, Arcioni S, Paolocci F (2007) Troubles with truffles: unveiling more of their biology. New Phytol 174:256-259

Rubini A, Belfiori B, Riccioni C, Tisserant E, Arcioni S, Martin F, Paolocci F (2011a) Isolation and characterization of MAT genes in the symbiotic ascomycete Tuber melanosporum. New Phytol 189: 710-722

Rubini A, Belfiori B, Riccioni C, Arcioni S, Martin F, Paolocci F (2011b) Tuber melanosporum: mating type distribution in a natural plantation and dynamics of strains of different mating types on the roots of nursery-inoculated host plants. New Phytol 189:723-735

Rubini A, Belfiori B, Riccioni C, Paolocci F (2012) Genomics of Tuber melanosporum: new knowledge concerning reproductive biology, symbiosis, and aroma production. In: Edible Ectomycorrhizal Mushrooms, Current Knowledge and Future Prospects (A. Zambonelli and G.M. Bonito eds.). doi 10.1007/978-3-642-338236_4, Springer-Verlag Berlin Heidelberg, pp 57-72

Rubini A, Riccioni C, Belfiori B, Paolocci F (2014) Impact of the competition between mating types on the cultivation of Tuber melanosporum: Romeo and Juliet and the matter of space and time. Mycorrhiza 24:19-27

Selosse MA, Martin F, Bouchard D, le Tacon F (1999) Structure and dynamics of experimentally introduced and naturally occurring Laccaria sp. Discrete genotypes in a Douglas fir plantation. Appl Environ Microb 65:2006-2014 
Selosse MA, Taschen E, Giraud T (2013) Do black truffles avoid sexual harassment by linking mating type and vegetative incompatibility? New Phytol 199:10-13

Shiu PKT, Glass NL (1999) Molecular characterization of tol, a mediator of mating-type-associated vegetative incompatibility in Neurospora crassa. Genetics 151:545-555

Teramoto M, Wu B, Hogetsu T (2012) Transfer of ${ }^{14} \mathrm{C}$-photosynthate to the sporocarp of an ectomycorrhizal fungus Laccaria amethystina. Mycorrhiza 22:219-225

Treseder KK, Turner KM, Mack MC (2007) Mycorrhizal responses to nitrogen fertilization in boreal ecosystems: potential consequences for soil carbon storage. Glob Change Biol $13: 78-88$
Urban A, Neuner-Plattner I, Krisai-Greilhuber I, Haselwandter K (2004) Molecular studies on terricolous microfungi reveal novel anamorphs of two Tuber species. Mycol Res 108:749-758

Weden C, Danell E, Camacho FJ, Backlund A (2004) The population of the hypogeous fungus Tuber aestivum syn. T. uncinatum on the island of Gotland. Mycorrhiza 14:19-23

Zampieri E, Balestrini R, Kohler A, Abbà S, Martin F, Bonfante P (2011) The Perigord black truffle responds to cold temperature with an extensive reprogramming of its transcriptional activity. Fungal Genet Biol 48:585-591

Zhou Z, Miwa M, Matsuda Y, Hogetsu T (2001) Spatial distribution of the subterranean mycelia and ectomycorrhizae of Suillus grevillei genets. J Plant Res 114:179-185 